\title{
CUSTOMERS' OPINION ON THE MIZSE MINERALWATER IN KECSKEMÉT AND ITS NEIGHBOURING SETTLEMENTS

\author{
${ }^{1} B$. Zsótér, ${ }^{2}$ R. Balog
}

${ }^{1}$ University of Szeged, Faculty of Engineering, Mars tér 7, H-6724, Szeged, Hungary e-mail: zsoterb@mk.u-szeged.hu

\begin{abstract}
In this article we studied one aspect of consumer's habit, namely the consumption of mineral water in the middle of Hungary. We applied so-called multiple methodology during the field work. We carried out a questionnaire survey as main method of research in CBA-supermarkets of three different settlements. The major part of the consumers considered the price as the most important factor of purchase. They beleived the secret of the success of 'Mizse' in it. The interest in the pack of 0.5 litre was surprisingly great. The product of this size of packing has been released later. Almost $58 \%$ of the costumers buying 'Mizes-water' would certainly try the fizzy drink called 'Mizse-lemon soda', too. The initial results echoe the need of further investigation.
\end{abstract}

Keywords: mineral water, packaging, consumption behaviour, price, brand, factors influencing purchase

\section{INTRODUCTION}

We carried out our research in connection with the 'Mizse-water' of the company called Magyarvíz Ásványvíz Korlátolt Felelősségü Társaság (briefly: Magyarvíz Kft.) which water won „The Product of the Year"-prize in 2012 and 2013. What is the secret of its success? Its favourable price? Its mineral content? Its quality?

During our research we visited the company where we were welcomed helping us to compile the questionnaire and giving us the necessary statistical data.

The purpose of our research was to examine the reasons for the popularity of 'Mizse-water'. The relating survey was carried out in three different places (determined by the producer): in CBA-supermarkets in Kecskemét, Lajosmizse and Kerekegyháza. We accomplished our survey on 5th and 7th June, 2014 in Kecskemét, on 14th June in Lajosmizse and on 21st June in Kerekegyháza. We had the following hypotheses:

- The packaging of 0.5 litre would be popular among costumers. Perhaps $2 / 3$ of the respondants would buy it. (It was not sold at the time of the survey.)

- We assumed that the most influencing factor of purchase (the custumers' s decision) would be the price of the products. It is followed by the good quality and then the placeof origin as a sort of local performance.

- At least half of the respondants would buy the 'Mizse-lemon soda' product.

We intended either to prove or reject these hypotheses.

\section{LITERATURE OVERVIEW}

According to the surveys carried out by the European Federation of Bottled Water (EFBW) the consumption of mineral water per person was 104.3 litre as an average in the EU-24 countries in 2012. The highest indicators were in Italy (180.5 1/person/year) and Germany (177.1 1/person/year).

Hungary performs nearly average results in Europe. One person consumed 117.81 of mineral water in the given year which means that our country is ranked to the fourth place in the EU-24 countries. The annual consumption was 31 person/year in the 1980s and at the beginning of the 1990s. The consumption started to grow dynamically -by 20-30 \% per year- in 1993 and then in 2012 it reached the 1181 per person [1] [2].

In 2002 the companies Danone and San Benedetto founded the Magyarvíz Kft. as a green-field investment near Lajosmizse, by the motorway M5 [3] [4]. The production started here in 2003. The firm has achieved 
a number of outstanding classifications during the years which managed to rise its success: ISO9001-2009, the prize „Product of the Year” 2012/2013, IFS2012 (International Food Standard) [5] [6]. On the basis of the national sales data 'Mizse' is the fourth most popular bottled mineral water in Hungary. In 2012 it reached the increase of $60 \%$ in the category of cheap, 50-70 fts products in hypermarkets which was partly due to the fact that the product family won the prize „Product of the Year” [7]. According to the statistical data, it can be said that it was the Magyarvíz Kft which could reach the highest increase related to sales between Octobers of 2012 and 2013 with a value of $21 \%$. The data of August reflects the success again: the non-carbonated version of 'Mizse' is among the first five most popular bottled mineral water on the fourth place while the carbonated one is on the fifth place. Both of them show an increase in the examined period. $(17,5 \%, 0,5 \%)[8]$.

\section{MATERIAL AND METHODS}

We used both secondary and primary research methods in our work. The secondary research involved a short presentation of changes in consumption of mineral water in the European Union and Hungary, also we could have a look into the history, success and market position of the Magyarvíz Kft. Our primary research was carried out in the framework of a questionnaire survey. According to Bércziné [9] the most important methods of primary research are the inquiry, observation, experiment and the so-called other primary researches. We can distinguish qualitative and quantitative data collection: experts consider the qualitative methods generally more authentic while the quantitative methods more precise [10] [11]. We compiled the content of the questionnaire according to the methodological descriptions of Kotler and Keller [12], Malhotra [13], Scipione [14] and Magyar [15].

The questionnaire contains altogether 22 questions. Some of them are of demographical type, and the others are aimed to examine the opinion and satisfaction of the costumers. Following the principle of progressivity we started with general questions which related to the frequency of the consumption of mineral water, to the well-known brands and to other aspects. After that, we focused the questions to the product family 'Mizse'. We involved questions preferred by the company like for example packaging and questions about 'Mizse-lemon soda'. We finished the questionnaire with demographical questions which connected to the place of residence, educational attainment, sex and age.

We used the program SPPS Statistica, which helps process more complexed data basis quickly and effectively, to process and evaluate the questionnaires. The program involves a wide range of statistical methods: data base, descriptive statistics, other multi- variables statistical methods [16].

\section{DESCRIPTON AND EVALUATION OF THE RESULTS}

Altogether 252 people completed the questionnaire. Their composition by sex are as follow: $61 \%$ were women, 39\% were men. Most of the customers ranked to the age group 50-62 (60 people, 24\%).

Almost half of them (45.23\%) drink mineral water more times a day, $26.19 \%$ on a daily basis, $17.46 \%$ on a weekly basis.

The most frequently consumed mineral water brands chosen by the respondants were Natur Aqua, Szentkirályi, Zafír, Mizse, Theodora, Nestlé Aquarel. Besides, they named other brands, too, in a much smaller number: Emese, Jana, Verde, Vöslauer, Knjaz Milos, Balfi, Aquarius.

Only $66 \%$ of sample (166 people) think that it is important to drink national mineral water.

$84.52 \%$ of the respondants know and $79 \%$ of them buy the bottled water called 'Mizse'. However, exactly the opposite can be observed in the case of 'Mizse'-tea. 92\% of the answerers did not know the tea among the products which can be due to the fact that the firm does not really advertise its products. Only $56 \%$ of the people know the 'Primavera', while $68 \%$ of them the 'Zafír-water'.

Most of the customers purchase the 'Mizse' mineral water every week. $79 \%$ of the respondants choose more frequently the one in the 0.51 packing. 
What other packaging would be the subject of the customers purchase? $37.5 \%$ of them would like to see the one of $0.51,25 \%$ the bottle of 2.51 and $13 \%$ the pack of 51 (Fig. 1).

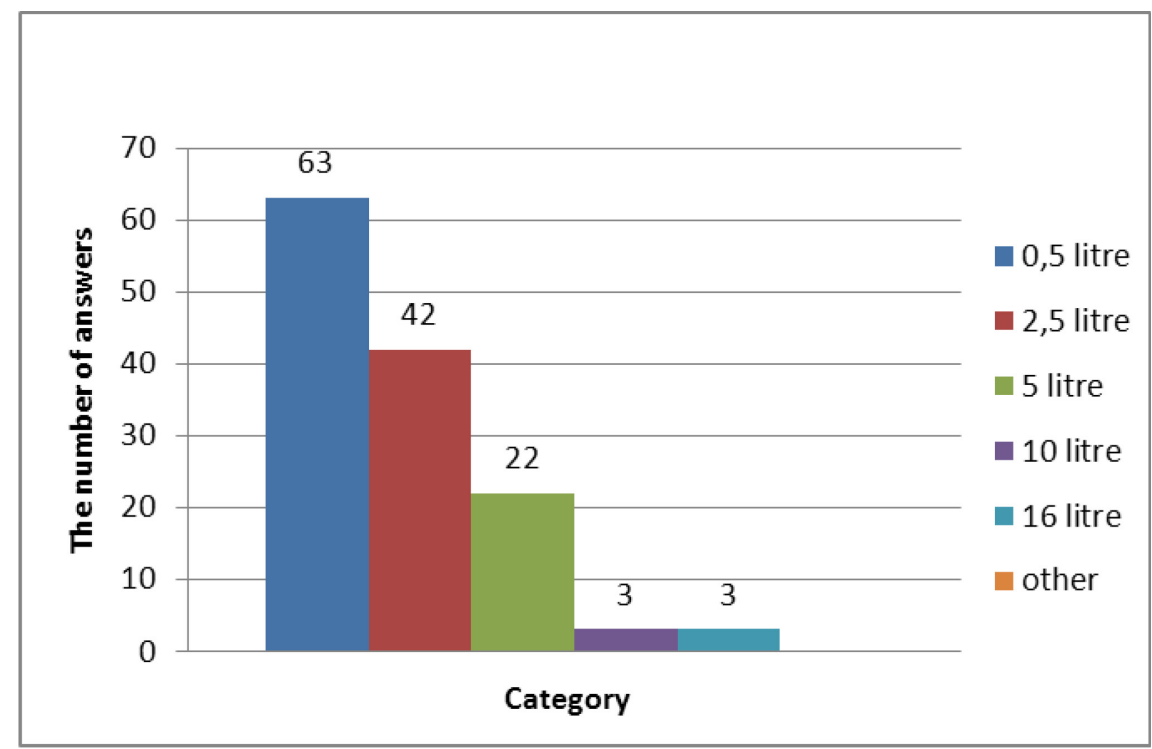

Figure 1. $n=168$ ) What other packaging would the customers like to purchase the 'Mizse' water? (n=168) The number of answers/Categories/litre/Other

Our next question was directed to explore how the customers see the quality of the 'Mizse-water'?

The answers reflectwhat the customers think about the quality of the 'Mizse-water'. $92 \%$ of them ranked it either to the category of medium or better. Within these three categories most people chose the 'good'one: $57 \%$ of the answerers chose this option. About a quarter of them considers it medium, while $10 \%$ outstanding.

For the respondants it is the price which influences most their choice, the mineral content and the place of origin were ranked to the second position, while the name of the product and its producer do not influence them.

Would you try to taste the 'Mizse-tea' or the 'Mizse-lemon soda'? The opinion of consumers of 'Mizse' mineral water is almost equal in connection with the tea. $53 \%$ said yes, $47 \%$ no. $58 \%$ of the respondants would try to taste the 'Mizse'-lemon soda, while $42 \%$ of them would not choose it, if it were released.

Which flavour would you choose, if you tried the tea?

The most popular flavour would be the lemon $(43 \%)$, it was followed by the cranberry-flavoured tea (37\%). The green tea occupied the third rank which would be bought by $34 \%$ of the respondants. The popularity of peach flavour was under $30 \%$. The less popular tea was the black one: only $11 \%$ would try this product. Other flavours were not mentioned in the survey.

How much would you pay for the tea or the soda (a bottle of 1.51), if you tried it?

$36 \%$ of the answerers would pay a sum between 100 and $130 \mathrm{fts}$ for the tea. About the same amount (17 and 20\%; 15 and 18 people) chose either less than $100 \mathrm{fts}$ or a sum between 130 and $160 \mathrm{fts}$ for the bottle of tea. About $6 \%$ would pay between 160 and $190 \mathrm{fts}$ for this sort of product.

Similar to the tea, most of the answerers chose the second category for the soda: $37 \%$ would pay a sum between 90 and $100 \mathrm{fts}$ for this product. 13\% less than $90 \mathrm{fts}$ and $18 \%$ a sum between 100 and $110 \mathrm{fts}$. Only $9 \%$ would pay between 110-120 fts for the 'Mizse'- lemon soda. 


\section{SUMMARY}

The result of our research according to the opening hypotheses.

1. According to our hypothesis the packaging of 0.51 would be popular amongstcustomers, more than two thirds of them would buy it. The survey shows different results. Only $38 \%$ of the customers would purchase this packaging, thus the hypothesis has not been confirmed. Although this $38 \%$ can be regarded as an important demand which was proved by the fact that the packaging of 0.51 has been launched in the market since the survey.

2. The hypothesis claims that the most influencing factor for the purchase is the price of product [17]t is followed by the mineral content and then the place of origin. It was partly proved to be true: in our survey we could experience that the most important factor is the price level. The mineral content as one of the quality indicators and the place of origin as local product [18] were ranked to the same place.

3. The hypothesis assumed that at least half of the consumers of the 'Mizse'-water would try to taste the 'Mizse'-lemon soda, as well. Almost 58\% of the consumers said that they would try the abovementioned product if it were in the market. This hypothesis has been confirmed.

During our research we observed that most of the customers appreciate the 'Mizse' mineral water of a good quality. It has also been proved that the price of the product is the most influencing factor for the answerers. In our opinion the popularity of the 'Mizse'- water embeds in these two factors: the costumers buy it with pleasure because they can get a product of a good quality for low price level. Provided the firm is still planning to produce tea, it would be practical to start with tea in flavours lemon and green tea. Our research underlined the assumption that more than the half of the respondents would try to buy the 'Mizse'lemon soda so it would be a good idea to introduce it to the market.

\section{REFERENCES}

[1] Nádasi T., Udud P.,Ásványvizek könyve, Aquaprofit Zrt, Budapest, 2007, pp. 48-150.

[2] http://efbw.eu/bwf.php?classement=07 (2014.03.14.)

[3] Ballai J.,Lajosmizsén a San Benedetto, Világgazdaság, 33(97) (2001), p. 15.

[4] Eötvös P., Francia-olasz palackozó Lajosmizsén, Népszabadság, 60(100) (2002), 29. p.

[5] Farkas P.J., Kiváló ásványvizek Mizséről, Kecskeméti lapok, 100(19) (2004), 3. p.

[6] Dékány S., Magyarvíz Kft.: Folyamatos innováció és minőségbiztosítás, Fogyasztóvédelem, 14(2) (2012), 27.

[7] Király E. (szerk.), Dupla annyi fogy az olcsóból, Petőfi Népe, 67(266) (2012), 5. p.

[8] Magyarvíz Kft. belső anyagai, Nielsen Magyarország által készített, a hazai ásványvízpiaccal kapcsolatos, 2012-2013 októberére vonatkozó kutatás

[9] Bércziné Juhos J.,Piac-és marketingkutatás a gyakorlatban, CO-NEX Könyvkiadó Kft., Budapest, 1999, pp. 43-74.

[10]Lehota J., Marketingkutatás az agrárgazdaságban, Mezőgazda Kiadó, Budapest, 2001, pp. 35-134.

[11]Gondi J., Ivánkai Gy. (2004): Marketing, Kereskedelmi és Idegenforgalmi Továbbképző Kft., Budapest, 17. p.

[12] Kotler P., Keller K.L.,Marketing Management, Pearson Education Inc., Prentice Hall, In.: Hoffmann I. (szerk.), Marketingmenedzsment, Akadémiai Kiadó Zrt., Budapest, 2006, pp. 205-276.

[13] Malhotra N.K., Marketing Research: An Applied Orientation, Pearson Education Inc., Prentice Hall, In: Veres Z.(szerk.), Marketingkutatás, KJK-KERSZÖV Jogi és Üzleti Kiadó, Budapest, 2002, pp. 361-370.

[14] Scipione P.A.,Practical Marketing Research, Kendall/Hunt Publishing Company, In.: Pásztor Gy. (szerk.), A piackutatás gyakorlata, Springer Hungarica Kiadó Kft, Budapest, 1994, 56. p.

[15] Magyar Z., Piackutatás, Nyíregyházi Főiskola, Nyíregyháza, 2010, pp. 54-80. 
[16]Huzsvai L. Biometriai módszerek az SPSS-ben. SPSS alkalmazások, Debreceni Egyetem Mezőgazdaságtudományi Kar, Debrecen, 2011, pp. 3-5.

[17] Végh K., Illés S. Hypothetical models of food consumption behaviour by the elderly. Lambert Academic Publishing, Saarbrücken, (2011).

[18]Illés S. Polgármesteri szemmel a turizmusról és a migrációról. Comitatus, 17(10) (2007) pp. 50-66. 